\title{
Analysis of Time Driven Activity Based Costing Implementation in Calculation of Cost Efficiency Level Capacity in Government Agencies (Case Study of KPP Pratama Binjai)
}

\author{
Dedy Antropov ${ }^{1}$, Iskandar Muda $^{2}$, Nisrul Irawati ${ }^{2}$ \\ ${ }^{1,2}$ Master of Management Study Program on Postgraduate School of University of Sumatera Utara, Indonesia.
}

Corresponding Author: Dedy Antropov

\begin{abstract}
Currently, Indonesia still uses tax revenue as the main source of state revenue. However, the problem occurred when for several years it turned out that tax revenues did not meet the target. The percentage of realized tax revenues compared to the tax revenue target from year to year indicates that the ratio of tax revenues did not reach the target. One of the factors causing the non-achievement of tax revenue is related to the number of employees of the Directorate General of Taxes who are still not ideal with their workload. This study aims to determine how to calculate the efficiency level of capacity costs by using the theory of Time Driven Activity Based Costing (TDABC) in the utilization of currently available resources at the Tax Service Office, Kantor Pelayanan Pajak (KPP) Pratama Binjai. The population of this research is all the executor of the Service Section and Account Representative who are in KPP Pratama Binjai. The researcher uses descriptive (qualitative) data analysis method which only aims to explain the observed facts/practices based on certain theories. This study uses primary and secondary data from KPP Pratama Binjai. The results show that through the TDABC theory, the level of capacity cost efficiency at KPP Pratama Binjai is included in the less efficient category, which means that there is still a lot of unused capacity that should be maximized from available capacity and used capacity.
\end{abstract}

Keywords: Time Driven Activity Based Costing (TDABC), Efficiency, Available Capacity, Used Capacity, Unused Capacity

\section{BACKGROUND}

As a developing country, Indonesia certainly really needs large funds to finance its state expenditures. Currently, Indonesia still uses tax revenue as the main source of revenue. However, the problem occurred when for several years, it turned out that tax revenues did not meet the target. Percentage of realized tax revenue compared to the tax revenue target from year to year shows that the tax revenue ratio does not reach the target.

One of the factors that are considered to be the cause of the nonachievement of tax revenues is related to the number of employees of the Directorate General of Taxes (DGT) who are still not ideal with their workload. Quoted from the news "Target Missed, Directorate General of Taxes Admits Implementing Wrong Strategy" by CNN Indonesia, Sigit Priadi Pramudito as Director General of Taxes at the time stated that currently the number of employee resources owned by DGT was still lacking. He explained that the ideal number of tax officials is around 62 thousand people. The limitations of the DGT in allocating these resources make the proper treatment of taxpayers not yet considered effective and efficient. This can be seen from the level of taxpayer compliance which is still in the range of $60 \%$ and has an impact on achieving a tax ratio that is not yet optimal, at $12 \%$. 
Optimization of resources can be done by managing resources or also called management of organizational capacity. Management of organizational capacity is carried out by calculating the costs incurred in financing the capacity that occurs in the organization. Through the measurement of the cost of the capacity, managers will be assisted in planning, budgeting, determining products or services, measuring organizational performance, to managing organizational resources or capacity. Knowledge of capacity costs will be able to increase management's awareness of potential inefficiencies and indicate opportunities (Cooper \& Kaplan, 1992).

Capacity is all the resources owned by the organization in order to produce goods or services to increase the value of the organization and consumers. Mc Nair and Vangermeersch (in Irwanti, 2014), define capacity as the organization's ability to create value and this ability is obtained from various types of resources owned by the organization. The calculation of capacity costs can be done using the Time Driven Activity Based Costing (TDABC) method. Besides being easy to implement, the advantages of TDABC are the availability of information related to company efficiency through the disclosure of data regarding the costs and execution time of each business process and the availability of information about available, used, and unused capacity (Anderson \& Kaplan, 2007).

In the private sector, the calculation of capacity costs to optimize organizational resources has been carried out by Szycta in a journal entitled Time Driven Activity Based Costing in Service Industries (2010). Szycta (2010) uses TDABC because there are several weaknesses or difficulties encountered in the implementation of traditional Activity Based Costing (ABC). These weaknesses include the development, implementation and updating of the $\mathrm{ABC}$ model which takes a long time and a complicated process so that the costs (material and non-material) are high. This has caused many companies to finally give up on adopting traditional ABC (Cooper et al. 1992, Argyris \& Kaplan, 1994, Shields, 1995, Friedman \& Lyne, 1998 in Szycta, 2010). Szycta suggests that TDABC can overcome the problems that arise when adopting ABC.

Meanwhile, in the public sector, the calculation of capacity costs to optimize organizational resources has been carried out by Stouthuysen et al. in 2010 . Stouthuysen et al. (2014) simulated and compared the use of TDABC in two public swimming pool facilities managed by the same local government. The result is that TDABC provides a wealth of useful information for managers in maximizing business processes, optimizing resources, and optimizing costs.

Based on these things, researchers are interested in conducting research on the cost of resources or capacity in government agencies using the TDABC method. The research will be conducted at the DGT vertical unit, namely the Tax Service Office (KPP) Pratama Binjai. KPP Pratama Binjai as a vertical agency of the DGT for years has not been able to achieve the realization of the tax revenue target charged.

\section{Cost}

Hansen and Mowen (2006), define cost as cash or cash equivalent value sacrificed to obtain goods or services that are expected to provide current or future benefits for the organization. It is said to be cash equivalent because non-cash sources can be exchanged for desired goods or services. In an effort to generate current and future benefits, the management of an organization must make various efforts to minimize the costs required to achieve certain benefits.

\section{Capacity}

Mc Nair and Vangermeersch (in Irwanti, 2014) say that capacity is the ability of an organization to create value where the ability is obtained from various types of resources owned by the organization. 
Capacity is the various resources owned by the organization, which are needed to generate value, either in the form of profit potential or in other ways. Capacity costs are cash or cash equivalent values incurred to provide various resources owned by the organization, to generate value in the form of potential profits or other things.

\section{Efficiency}

Mahmudi (2010) defines efficiency as a comparison between output and input or in other terms, output per unit of input. Mardiasmo (2004) defines efficiency as the achievement of output with certain inputs. Thus, it can be concluded that, efficiency is a condition when the implementation of a business with certain inputs is carried out correctly to produce the expected output with no wasted time, effort, and/or cost (waste). According to Mahmudi (2010), the concept of efficiency is a relative and not absolute concept. For example, a government unit $\mathrm{A}$ can be said to be more efficient than other government units, if a government unit A can use resources with smaller inputs than other units to produce the same output. A government unit can also be said to be more efficient if with the same amount of input, the unit can produce more output than other units. The concept of efficiency can also be related to productivity. Productivity is a comparison between input and output. For example, employee A can be considered more productive than other employees, if with the same amount of input and the same time allocation, employee A can produce more output than other employees.

\section{Time Driven Activity Based Costing}

$\mathrm{ABC}$ is a costing approach that is carried out by identifying individual activities as cost objects. The cause of the cost is the activities carried out by the organization. However, in its implementation the ABC system encountered several problems (Kaplan \& Anderson, 2007). First, ABC is difficult to implement by many organizations because of the high costs involved in conducting interviews and surveys of employees in the creation of the first ABC model. Everaert et al. (2008 in Nathalie et al. 2009) said that managers who tried to implement $\mathrm{ABC}$ in their organizations, finally gave up because of the increasing costs and the disruption felt by employees. The second is the determination of the time allocation for activities carried out by employees, which is carried out by conducting surveys, which often face problems because the activities have been carried out in the past. Employees have difficulty determining how much time is allocated to each activity. Third is the difficulty of maintaining or updating the ABC model. Maintaining or updating a finished ABC model would seem easy for a small part of the company. But it will be very difficult when the $A B C$ model has to be maintained and updated on a larger scale such as one whole company or a company that has multiple branches. This is because every time you maintain and update the ABC model, the survey must be carried out again, so that the costs incurred are increasing. In the end, organizations that implement $\mathrm{ABC}$ often rarely perform maintenance and updates on the $\mathrm{ABC}$ model, causing the model that has been created to be increasingly irrelevant. Fourth is on ABC, each activity has its own driver tariff. This makes it difficult to model an activity that has various complexities. Sometimes the same type of activity has a different level of ease of completion, i.e. some are easy to do, but some are more difficult. If only one fare driver is used for this activity, the information regarding the costs incurred will be inaccurate.

Because of these weaknesses, Kaplan and Anderson (2007) introduced the next ABC model called Time Driven Activity Based Costing (TDABC). TDABC is simpler, cheaper, faster to implement and update. TDABC only requires two main parameters, namely the cost per unit of available capacity and the time required to carry out one activity or transaction. The advantages of TDABC are that it can be 
estimated and applied quickly and easily to perform model updates in order to reflect process changes, order variations, and costs from resources/capacity, easily scalable to cope with many transactions while still providing fast processing and reporting times, confirms resource capacity (resource/supplied capacity), and able to show the capacity of resources that are not used (unused resource capacity).

\section{Public Sector Capacity Management}

Capacity management according to Ritchie and Walley (in Aasa \& Johansson, 2016) is a process for reconciling the resources needed to meet demand over time. Armistead and Clark (in Aasa \& Johansson, 2016) define capacity management as the ability to balance demand from consumers and the ability to provide services in order to meet demand. Thus, capacity management is reconciling or balancing the resources owned by the organization to meet demand from consumers over time.

TDABC helps implement capacity management by highlighting unused capacity. The value of unused capacity is obtained by subtracting the supplied capacity from the used capacity. Capacity management based on Jonsson and Mattsson (in Aasa and Johansson, 2016), is divided into two categories, namely medium term (2 - 18 months) and short term (less than one month).

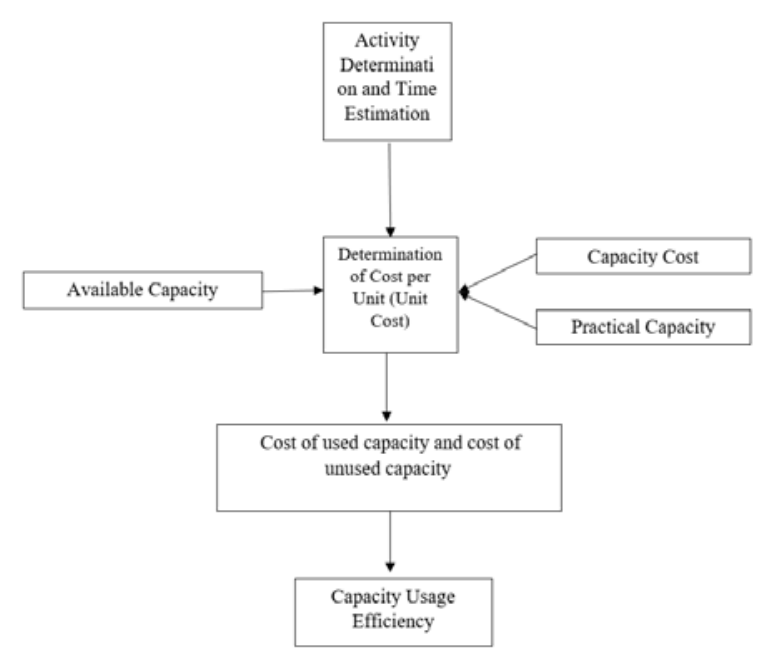

Figure 1: Research Concept Framework

\section{RESEARCH METHOD}

The research conducted at KPP Pratama Binjai regarding the application of TDABC in calculating the efficiency level of capacity costs is descriptive (qualitative) data analysis research. Regarding the number of population and samples in this study, the population that will be used is all employees with positions as executor of the service section and Account Representative. The total population for implementing the service section is 12 (twelve) people while the total population for Account Representatives is 57 (fifty seven) people. The entire population will be sampled in this study.

Primary data used in this study is data from interviews or observations that researchers obtained from various sources, both implementing the service section or Account Representative and other parties who have a direct relationship in processing research data. Secondary data used in this study can be in the form of qualitative data and quantitative data. Qualitative data consists of data on the number of employees, data on the floor area of the room, organizational operating procedures contained in the Standard Operating Procedure, archived data for outgoing letters, and so on. Quantitative data consists of Budget Realization Details Report data, employee salary cost data, State Property Reports and so on.

The data obtained were processed using the Time Driven Activity Based Costing method based on the journal from Kaplan and Anderson entitled Time Driven Activity Based Costing (2007) and Stouthuysen et al. (2014) with the title Time Driven Activity Based Costing for Public Service. After that, the efficiency level of capacity utilization was determined based on the efficiency formula proposed by Mahmudi in his book entitled Public Sector Performance Management (2010). 


\section{RESULT AND DISCUSSION Activity analysis and time estimation}

Activity analysis is the initial stage in starting the TDABC model where TDABC itself is a methodology with a bottom-up pattern that calculates the costs of all resources (Martin, 2018). In identifying activities, companies must be able to sort out the activities carried out in producing a product and determine the costs consumed by these activities (Kristina \& Faliany, 2016). The activities of Account Representatives in the Supervision and Consultation Sections I, II, III, IV and the Extensification and Counseling Section and Service Section Executors in 2019 are based on the Decree of the Minister of Finance Number 387/KMK.1/2018 concerning Structural Position Descriptions in Vertical Agencies and Units Technical Implementers within the Directorate General of Taxes and Director General of Taxes Decree Number KEP-167/PJ/2015 concerning Standard Operating Procedures for New, Revised, and Delete Semester I Year 2015 within the Directorate General of Taxes. The activities contained in the two regulations are collected and grouped so as to produce the activities listed in the Employee Performance Targets (SKP) every year.

After analyzing the activities of the Account Representative and Service Section Executor, the next step is to determine the estimated execution time of each activity that has been determined. Determination of the estimated time required to carry out activities is carried out to determine the time capacity needed so that it can calculate the rate for each activity later (Kristina \& Faliany, 2016). In determining the estimated execution time of each activity, this is done through direct observation or through interviews/surveys of all samples, both Account Representatives and Service Section Executives (Kaplan \& Anderson, 2007).

\section{Determining the cost per minute (unit cost)}

After knowing the practical capacity of each employee, the next step is to calculate the cost per minute (unit cost) by calculating in advance the total cost of capacity or the costs incurred to finance the capacity of the Account Representative and Service Section Executor during 2019. Capacity costs according to Stouthuysen et al. (2014), divided into five categories, namely wages, energy costs, maintenance costs, depreciation costs and overhead costs. In this study the five categories of costs are divided into direct costs and indirect costs. Direct costs consist of salaries and benefits, energy costs (electricity subscription costs), maintenance costs and depreciation costs. The cost of salaries and benefits takes into account all salaries, allowances, meals and overtime pay. Maintenance costs and depreciation costs take into account the costs of maintaining and depreciating equipment, machinery and buildings. Indirect costs that are taken into account are overhead costs in the form of costs for using office stationery.

1. The cost per minute of carrying out the Account Representative activity for the Supervision and Consultation Section I KPP Pratama Binjai for 2019 is IDR 2,701 per minute, which is generated by dividing the total cost by practical capacity during 2019.

2. The cost per minute of carrying out the Account Representative activity for the Supervision and Consultation Section II of KPP Pratama Binjai for 2019 is IDR 2,930 per minute, which is generated by dividing the total cost by practical capacity during 2019.

3. The cost per minute of carrying out the Account Representative activity for the Supervision and Consultation Section III of KPP Pratama Binjai for 2019 is IDR 2,897 per minute, which is generated by dividing the total cost by practical capacity during 2019.

4. The cost per minute of carrying out the Account Representative activity of the 
Supervision and Consultation Section IV of KPP Pratama Binjai for 2019 is IDR 2,858 per minute, which is generated by dividing the total cost by practical capacity during 2019.

5. The cost per minute of carrying out the Account Representative activity of the Extensification and Counseling Section of KPP Pratama Binjai for 2019 is IDR 2,946 per minute, which is generated by dividing the total cost by practical capacity during 2019.

6. The cost per minute of carrying out the activities of the KPP Pratama Binjai Service Section Executors for 2019 is IDR 2,064 per minute, which is generated by dividing the total cost by practical capacity during 2019.

\section{Available, Used, and Unused Capacity Costs}

The cost of used capacity is calculated by multiplying the cost per minute of carrying out activities by the number of activities that have been carried out during 2019. Based on Employee Performance Target data, it can be seen the number of activities produced by each Account Representative and Service Section Executor during 2019. Performance Target Data Employees who describe the number of activities carried out are based on the number of output targets that have been determined by the Directorate General of Taxes. From the amount of Employee Performance Target data, researchers take advantage of the number of activities carried out to be used for Account Representatives and Service Section Executors.

Table 1: Section Account Representative Capacity Fee

\begin{tabular}{|l|r|r|r|r|r|r|}
\hline Capacity Type & SC Section I & SC Section II & SC Section III & SC Section IV & EC Section & SSE Section \\
\hline Available Capacity & 1.361 .525 .652 & 2.616 .521 .035 & 2.588 .001 .166 & 2.647 .188 .439 & 2.183 .543 .291 & 2.245 .768 .856 \\
\hline Used Capacity & 516.524 .295 & 94.861 .680 & 110.294 .584 & 106.180 .416 & 2.088 .599 .106 & 4.280 .239 .806 \\
\hline Unused Capacity & 845.001 .357 & 2.521 .659 .355 & 2.477 .706 .582 & 2.541 .008 .023 & 94.944 .185 & \\
\hline
\end{tabular}

\section{Benefits of Capacity and Efficiency Costing Based on Time Driven Activity Based Costing Method}

The information generated from the calculation of capacity costs and efficiency levels is based on the Time Driven Activity Based Costing method, especially by making comparisons between more than one section so that it can be used to assist office management (head of office) in managing existing resources or capacity so that the desired output can be achieved. generated by the organization can be maximized. The application of TDABC helps in identifying the efficiency of the activities carried out and the costs incurred (Kristina \& Faliany, 2016). The TDABC model is considered very effective because it is able to capture and report cost data for each activity carried out (Stouthuysen et al, 2014).

\section{CONCLUSION}

1. Allocation of direct costs (salaries and allowances costs, energy costs, maintenance costs and depreciation costs) and indirect costs (overhead costs) to resources in each sample is represented at capacity costs with the value of capacity costs for Account Representative Supervision and Consulting Section I amounted to Rp. 1,361,525,652., for Account Representatives of the Supervision and Consultation Section II of Rp. 2,616,521,035., for Account Representatives of the Supervision and Consultation Section III of Rp. 2,588,001,166., for Account Representatives of the Supervision and Consultation Section IV of Rp. 2,647. 188,439., for Account Representatives for Extensification and Counseling Section of Rp. 2,183,543,291, for 
Service Section Implementers of Rp. 2,245,768,856;

2. The cost for the available capacity at the Account Representative Section for Supervision and Consultation I is Rp. $1,361,525,652$. The cost for the used capacity is IDR 516,524,295. Meanwhile, the cost for unused capacity is Rp. 845.001,357.

The cost for the available capacity at the Account Representative Section for Supervision and Consultation II is Rp. $2,616,521,035$. The cost for the used capacity is Rp. 94,861,680. Meanwhile, the cost for unused capacity is IDR 2,521,659,355.

The cost for the available capacity at the Account Representative for Supervision and Consultation Section III is Rp. $2,588,001,166$. The cost for the used capacity is Rp. 110,294,584. Meanwhile, the cost for unused capacity is Rp. 2,477,706,582.

The cost for the available capacity at the Account Representative for Supervision and Consultation Section IV is Rp. $2,647,188,439$. The cost for the used capacity is Rp 106,180,416. Meanwhile, the cost for unused capacity is Rp. 2,541,008,023.

The cost for the available capacity at the Account Representative Section of Extensification and Counseling is Rp. 2,183.543,291. The cost for the used capacity is Rp. 2,088,599,106. Meanwhile, the cost for unused capacity is Rp. 94,944,185.

The cost for the capacity available to the Service Section Executors is IDR $2,245,768,856$. The cost for the used capacity is Rp 4,280,239,806. Meanwhile, the cost for unused capacity is Rp. 0 ;

3. The highest level of efficiency in the use of capacity in the research sample of KPP Pratama Binjai is the Service Section Executors. The lowest level of efficiency is in the Account Representative Section of Supervision and Consultation II. The level of efficiency in the use of the Account Representative capacity of the Supervision and Consulting Section I is $37 \%$, the efficiency level of the use of the Account Representative capacity of the Supervision and Consultation Section II is 3.62\%, The efficiency level of the use of the capacity cost of the Account Representative for the Supervision and Consultation Section III is $4.2 \%$, The level of efficiency in the use of the Account Representative capacity of the Supervision and Consultation Section IV is $4.01 \%$, the efficiency level of the use of the capacity of the Account Representative for the Extensification and Counseling Section is $95.6 \%$, and the efficiency level of the use of the capacity costs of the Service Section implementers is $190 \%$. . Of the six research samples studied, it turns out that there is only one research sample whose efficiency level is above $100 \%$ which indicates that the use of available capacity and used capacity has been maximized. Meanwhile, the five research samples showed an efficiency level below 100\%. This shows that there is still quite a lot of room in maximizing the efficiency level in the five samples. In addition, an efficiency level that exceeds $100 \%$ is also a suggestion to managers that there are activities that exceed the cost of available capacity which is a signal that there is a lot of work but too few employees; and

4. Based on the results of the calculation of capacity costs using the Time Driven Activity Based Costing method, there are excess capacity in the five samples studied. This number shows that there is a waste of budget use because the costs that have been spent are not used optimally. TDABC gives managers the opportunity to see opportunities for improvement through cost management. TDABC also shows how to better manage costs. Through TDABC, managers can see how the use of 
existing resources in achieving the expected goals. The existence of this large excess capacity is due to the workload that must be borne by the research samples not being able to maximize all available capacity during 2019. Salaries and employee benefits are the burden or expense that dominates the cost of capacity, which is above $90 \%$. The efficiency of this greatest cost cannot be limited by termination of employees because the employees are State Civil Apparatus. The solution to this problem is to re-allocate capacity and adjust capacity. Savings on the type of cost or on the type of input salary and employee benefits will have a very large impact on increasing the level of efficiency and decreasing the value of unused capacity.

\section{Conflict of Interest: None}

\section{REFERENCES}

1. Aasa, Ida, Victor Johansson. 2016. A Framework for Capacity Management in the Public Sector - A Case Study of the Swedish Migration Agency [Thesis]. Gothenburg: Chalmers University of Technology.

2. Aditya, Muamar. 2010. Perhitungan Idle Capacity Dengan Menggunakan CAM-I Capacity Model Dalam Rangka Efisiensi Biaya Pada PT Bumi Tangerang Coklat Utama [Skripsi], Depok : Universitas Indonesia.

3. Akhavan, Sina., Ward, L., dan Kevin J. B. 2015. Time - Driven Activity - Based Costing More Accurately Reflects Costs in Arthroplasty Surgery. Clinical Orthopaedics and Related Research 474:8-15.

4. Alves, Rafael J. Vargas., Etges, A. P. B. S., Neto, G. B., Polanczyk, C. A. 2018. Activity - Based Costing and Time Driven Activity - Based Costing for Assessing the Costs of Cancer Prevention, Diagnosis, and Treatment: A Systematic Review of the Literature. Elsevier Inc. Value in Health Regional Issues 17: 142 147.

5. AM, Masyhudi. 2008. Analisis Biaya dengan Metode Activity Based Costing Kepaniteraan Klinik Mahasiswa Fakultas
Kedokteran Unissula di Rumah Sakit Pendidikan (Studi Kasus di Rumah Sakit Islam Sultan Agung) [Tesis]. Semarang : Universitas Diponegoro Semarang.

6. Amiri, Nabeel Al dan Seham El Khmidi. 2019. Implementing Time - Driven Activity - Based Costing (TDABC) in Out-Patient Nursing Department: A Case from UAE. Management Science Letters. 9 (2019) : 365 -380 .

7. Andalya, E. dan L. Lesetedi. 2019. Application of Time Driven Activity Based Costing in Botswana Open University. Pan - Commonwealth Forum. Edinburg Scotland.

8. Aningrum, Rinda Wahyu., Rachmadita, R.N., dan Aditya M. 2019. Analisa Perhitungan Harga Pokok Produksi Bogie 1014 dengan Metode Time Driven Activity Based Costing (TDABC) Analysis (Studi Kasus Pada Perusahaan Manufaktur Alat Transportasi). Proceedings Conference on Design Manufacture Engineering and Its Application.

9. Ardiansyah, Garry Billy., Tjahjadi, Bambang., dan Noorlailie S. 2017. Measuring Customer Profitability Through Time - Driven Activity - Based Costing : A Case Study at Hotel X Jogjakarta. SHS Web of Conferences. 34.

10. Arikunto. 2005. Manajemen Penelitian. Jakarta : Rineka Cipta.

11. Aujirapongpan, Somnuk., Promma, W., Theinsathid, P., Deelers, S., dan Suchavadee Meechal. 2020. The Application of Activity - Based Costing For Public Hospital Sector Sustainibility. Journal of Southwest Jiaotong University. Vol. 55 No. 5

12. Basri, Hasan. 2001. Penentuan Harga Pokok Produksi Air PDAM Kota Semarang dengan Metode Activity Based Costing Sebagai Alternatif [Tesis]. Semarang : Universitas Diponegoro.

13. Basuki, Bas dan Mertzha Dwiputri Riedansyaf. 2014. The Application of Time - Driven Activity - Based Costing in The Hospitality Industry : An Exploratory Case Study. Jamar 12 (1).

14. Blocher, E.J. et al. 2000. Manajemen Biaya : dengan Tekanan Stratejik. Terjemahan dari : A Susty Ambarriani. Jakarta : Salemba Empat.

15. Brignall, T.J. et al. 1991. Performance Management in Service Business. London : CIMA. 
Dedy Antropov et.al. Analysis of time driven activity based costing implementation in calculation of cost efficiency level capacity in government agencies (case study of KPP Pratama Binjai).

16. Brown, Richard E. et al. 1996. Activity Based Costing in Government : Possibilities and Pitfalls. Ohio : Blackwell Publishing.

17. Carter, William K. Dan Milton F. Usry. 2004. Akuntansi Biaya, buku 1. Edisi ke-13. Terjemahan dari : Krista. Jakarta : Salemba Empat.

18. Chea, Ashford C. 2011. Activity Based Costing System in Service Sector : A Strategic Approach for Enhancing Managerial Decision Making Competitiveness. International Journal of Business and Management. $6: 3-10$.

19. Childers, Christopher P. dan Melinda Maggard - Gibbons. 2018. Understanding Costs of care in the Operating Room. American Medical Association.

20. Cidav, Zuleyha., Mandell, David., Pyne, J., Beidas, R., Curran, G., dan Steven M. 2020. A Pragmatic Method for Costing Implementation Strategies Using Time Driven Activity - Based Costing. Implementation Science : 15 - 28.

21. Cokins, Gary. 2001. Activity Based Cost Management An Executive's Guide. New York : John Willey \& Sons, Inc

22. Cooper, Robin. and Anderson, Steven R. 2007. Time Driven Activity Based Costing. Boston : Harvard Business School Press.

23. Cooper, Robin. and Kaplan, Robert S. 1991. The Design of Cost Management Systems : Text, Cases and Readings. New Jersey : Prentice - Hall.

24. Demeere, Nathalie et al. 2009. Time Driven Activity Based Costing in an Outpatient Clinic Environment : Development, Relevance, and Managerial Impact. Ireland. Elsevier.

25. Dewi, Ni Wayan Yulianita., Gusti A. K. R. S. D., dan Made A. W. 2018. Use of Time Driven Activity - Based Costing to Calculate the Unit Cost per Students at Faculty of Economics of Universitas Pendidikan Ganesha. Advances in Economic, Business and Management Research 69.

26. Dyk, Jacob Van., Zubizarreta, E., dan Yolande L. 2017. Cost Evaluation to Optimise Radiation Therapy Implementation in Different Income Settings : A - Time Driven Activity - Based Analysis. Elsevier Ireland Ltd. Radiotherapy and Oncology $125: 178-185$.

27. Ely, Mira., Effendi, R., dan Imam M. 2019. Penerapan Time Driven Activity Based
Costing (TDABC) Dalam Perhitungan Kos Service Pada Bengkel HBBA. Jurnal Akuntansi Universitas Jember 17 (2).

28. Etges, Ana Paula Beck da Silva et al. 2020. Time - Driven Activity - Based Costing As A Strategy to Increase Value : The Case of Interventional Procedures. BMC Health Services Research.

29. Fitriasari, Dewi dan Naoko Kawahara. 2019. The Time - Driven Activity - Based Costing Model for a Small Startup in Indonesia. Binus Business Review 11 (2) : $141-148$.

30. Garrison, Ray H. and Noreen, Eric W. 2000. Managerial Accounting : Akuntansi Manajerial. Jakarta : Salemba Empat.

31. Garrison, Ray H. and Noreen, Eric W. 2000. Managerial Accounting : Akuntansi Manajerial, buku 2. Jakarta : Salemba Empat.

32. Guzman, Lorena S et al. 2015. Using Time Driven Activity Based Costing to Identify Best Practice in Academic Libraries. Liber Quarterly. 23 : 160-186.

33. Hansen, Don R. and Mowen, Maryanne M. 2005. Akuntansi Manajemen, jilid 1, penerjemah Angella A. Hermawan. Jakarta : Erlangga.

34. Hansen, Don R. and Mowen, Maryanne M. 2006. Akuntansi Manajemen, buku 1. Edisi ke-7. Jakarta : Salemba Empat.

35. Hansen, Don R. and Mowen, Maryanne M. 2006. Cost Management : Accounting and Control. Edisi ke-15. United States : Thomson Southwestern.

36. Horngren, Charles $\mathrm{T}$ et al. 2012. Cost Accounting : A Managerial Emphasis. Edisi ke-14. New Jersey : Pearson.

37. Husted, Henrik., Kristensen, B. B., Andreasen, S. E., Nielsen, C. S., Troelsen, A. dan Kirill G. 2018. Time - Driven Activity - Based Cost of Outpatient Total Hip and Knee Arthroplasty in Different Set - Ups. Acta Orthopaedica 89 (5) : 515 521.

38. Irwanti, Dertania. 2014. Analisis Biaya Kapasitas di Instansi Pemerintah Dengan Menggunakan Time Driven Activity Based Costing (Studi Kasus Kantor Pelayanan Pajak Madya Malang) [Skripsi], Tangerang Selatan : Sekolah Tinggi Akuntansi Negara.

39. Jones, Rowan and Maurice Pendleburry. 2000. Public Sector Accounting. Edisi ke-5. Essex : Pearson Education Limited. 
Dedy Antropov et.al. Analysis of time driven activity based costing implementation in calculation of cost efficiency level capacity in government agencies (case study of KPP Pratama Binjai).

40. Jovanka, Astrid Anastasya dan L. Jade Faliany. 2017. Penerapan Time - Driven Activity - Based Costing Pada Perhitungan Harga Pokok Produk Usaha Jasa Unixon. Jurnal Akuntansi 11 (1).

41. Kaplan, Robert S. dan Steven R. Anderson. 2007. Time Driven Activity Based Costing. Harvard Business School Publishing Corporation.

42. Keel, George., Muhammad, Rafiq., Savage, Carl., Spaak, Jonas., Gonzalez, Ismael., Lindgre, Peter. Guttman, Christian., dan Parnela M. 2020. Time - Driven Activity Based Costing for Patients With Multiple Chronis Conditions : A Mixed - Method Study to Cost Care in A Multidisciplinary and Integrated Care Delivery Centre at A University - Affiliated Tertiary Teaching Hospital in Stockholm. Sweden. BMJ Open 10.

43. Kristina, Indira dan Faliany L. Jade. 2016. Penerapan Time - Driven Activity Based Costing Pada Perhitungan Harga Pokok Produksi Jasa di PT Ernest Advisory. Jurnal Akuntansi $1: 41-51$.

44. Kristono, Alwan Sri, dan Ardhya Yudistira Adi Nanggala. 2020. Activity Based Costing Dengan Kendali Waktu Untuk Menghitung Cost Layanan Pada Bengkel Otomotif "DA" di Jember. El Muhasaba : Jurnal Akuntansi 11.

45. Kumar, Nitin and Mahto, Dalgobind. 2013. A Comparative Analysis and Implementation of Activity Based Costing (ABC) and Traditional Cost Accounting (TCA) Methods in an Automobile Parts Manufacturing Company : A Case Study. Global Journal of Management and Business Research Accounting and Auditing $13: 1-11$.

46. Kurniawansyah, Deddy. 2020. Kinerja UMKM di Kabupaten Jember : Studi Empiris Sebelum dan Sesudah Penerapan Metode Time - Driven Activity - Based Costing. Jurnal Riset Akuntansi dan Bisnis Airlangga 5.

47. Mahmudi. 2010. Manajemen Kinerja Sektor Publik. Edisi ke-2. Yogyakarta : UPP STIM YKPN.

48. Mardiasmo. 2004. Akuntansi Sektor Publik. Yogyakarta : Andi.

49. Martin, Jacob A. et al. 2018. Using Time Driven Activity - Based Costing as a Key Component of the Value Platform : A Pilot Analysis of Colonoscopy, Aortic Valve
Replacement and Carpal Tunnel Release Procedures. Journal of Clinical Medicine Research 10 : 314 - 320 .

50. Mohammadpour, Farzaneh., Basakha, Mehdi., Kamal, S.H.M., dan Nadia A. 2020. Costing the Outpatient Rehabilitation Services : Time - Driven Activity Based Costing Approach. BMC Health Services Research.

51. Moleong, Lexy J. 2007. Metodologi Penelitian Kualitatif. Bandung : PT Remaja Rosdakarya.

52. Mulyadi. 2003. Activity - Based Costing System. Edisi ke-6. Yogyakarta : UPP AMP YKPN

53. Mulyadi. 1993. Akuntansi Biaya. Edisi ke5. Yogyakarta : STIE YKPN.

54. Narvy, Steven. J., Ahluwalia, Avtar., dan Thomas V. 2016. Analysis of Direct Costs of Outpatient Arthroscopic Rotator Cuff Repair. The American Journal of Orthopedics.

55. Oktavia, Deni. 2013. Implementasi Time Driven Activity Based Costing (TDABC) pada Usaha Kecil Menengah (UKM) Tape Handayani 82 Bondowoso. Jurnal Akuntansi Universitas Jember 1-19.

56. Rai, I Gusti Agung. 2010. Audit Kinerja Sektor Publik. Jakarta : Salemba Empat.

57. Rakotondrajoa, Philippe., Rakotomamonjy, T., Baptiste, R.J., Demers, L., Kileo, P., Anholt, M., Aghajanian, J., dan Ken B. 2020. Achieving Self - Sustainability of Service Delivery in An Eye Care Program in Madagascar Using Time - Driven Activity Based Costing. BMC Health Services Research. $20: 205$.

58. Rayburn, L. Gayle. 1999. Akuntansi Biaya : Dengan Menggunakan Pendekatan Manajemen Biaya. Edisi ke-6. Jilid I. Penerjemah Sugyarto. Jakarta : Erlangga.

59. Roman, Erin., Cardoen, E., Decloedt, J. dan Filip R. 2020. Variability in Hospital Treatment Costs : A Time - Driven Activity - Based Costing Approach for Early - Stage Invasive Breast Cancer Patients. BMJ Open 10.

60. Ryan, Juanelo dan Lim Jade Faliany. 2018. Penerapan Time - Driven Activity Based Costing Pada Perhitungan Harga Pokok Kamar Penginapan Pondok Impian. Balance : Jurnal Akuntansi, Auditing dan Keuangan 15.

61. Spence, Frank W. 1993. Activity Based Costing in A Service Organization [Tesis]. 
Dedy Antropov et.al. Analysis of time driven activity based costing implementation in calculation of cost efficiency level capacity in government agencies (case study of KPP Pratama Binjai).

California : Naval Postgraduate School Monterey.

62. Suryanto., Rasmini, Mas., dan Thealice L. 2020. Activity Based Costing : Accurate Methods Determining Hotel Room Cost. Jurnal Pemikiran dan Penelitian Administrasi Bisnis dan Kewirausahaan 5 : $51-62$.

63. Stouthuysen, Kristof et al. 2014. Time Driven Activity Based Costing for Public Service. Public Money Management. Public Money \& Management. 34 : 289 - 296.

64. Suteja, Diana., Purwanto, D.A., Romadhon, P.Z., Putri, A.E., dan Retno H.O. 2020. Cost Reduction Using the Time Driven Activity Based Costing Method for Chemotherapy Treatment Costs for Breast Cancer Patients In the Era of National Health Insurance (JKN) at Airlangga University Hospital. Indian Journal of Public Health Research \& Development 11.

65. Sycta, Anna. 2010. Time Driven Activity Based Costing in Service Industries. Social Sciences/Socialiniai Mokslai 67 : 49 - 60.

66. Tanis, Veyis Naci. And Ozyapici. 2012. The Measurement and Management of Unused Capacity in a Time Driven Activity Based Costing System. Jamar $10: 43-56$.

67. Tse, Michael S.C. and Maleen Z. Gong. 2009. Recognition of Idle Resource in Time Driven Activity Based Costing and Resource Consumption Accounting Models. Jamar $7: 41-54$.
68. Vazakidis, Athanasios dan Eleftheria Kyriakidou. 2020. Time - Driven Activity Based Costing in the Public Sector, The Case of Greek General Chemical State Laboratory under the Greek Crisis. Journal of Social Sciences $16: 49-58$.

69. Vedernikova, Olga., Guzman, L. S., Pesantez, J. dan Rodrigo A. C. 2020. Time Driven Activity - Based Costing in the Assembly Industry. Australasian Accounting, Business and Finance Journal 14 (4).

70. Yonpae, Park., Sungwoo, J. dan Jahmani Y. 2019. Time - Driven Activity - Based Costing Systems For Marketing Decisions. Studies in Business and Economics 14 (1).

71. Yu, Yangyang $\mathrm{R}$ et al. 2016. Time Driven Activity Based Costing to Identify Opportunities for Cost Reduction in Pediatric Appendectomy. Journal of Pediatric Surgery 51 : 1962 - 1966.

72. Weygandt, Jerry J et al. 2012. Managerial Accounting ; Tools For Business Decision Making. Edisi ke-6. Danvers. John Wiley \& Sons, Inc.

How to cite this article: Dedy Antropov, Iskandar Muda, Nisrul Irawati. Analysis of time driven activity based costing implementation in calculation of cost efficiency level capacity in government agencies (case study of KPP Pratama Binjai). International Journal of Research and Review. 2021; 8(12): 393-403. DOI: https://doi.org/10.52403/ijrr.20211248 